\title{
Lactobacillus hordniae, a New Species from the Leafhopper (Hordnia circellata)
}

\author{
B. A. LATORRE-GUZMAN, C. I. KADO, AND R. E. KUNKEE \\ Department of Plant Pathology and Department of Viticulture, University of California, Davis, \\ California 95616
}

\begin{abstract}
A gram-positive, rod-shaped bacterium, originally thought by Auger (1974) to be the agent of Pierce's disease of grapevines, is commonly associated with Hordnia circellata, one of the leafhopper vectors of the disease. The bacterium has the following colonial and cellular characteristics: smooth, glistening white, or chalky colonies, 0.4 to $0.5 \mathrm{~mm}$ in diameter with entire margins; gram positive becoming gram variable after 5 days in culture; nonmotile and nonsporeforming; grows between 15 and $37^{\circ} \mathrm{C}$ with an optimum between 28 and $30^{\circ} \mathrm{C}$ and no growth at 9 or $45^{\circ} \mathrm{C}$; optimum growth occurs at $\mathrm{pH} 6.5$, with growth observed at pH 4.5 and pH 9.0. The bacterium does not survive after 5 to 7 days of growth and must be maintained on fresh medium. It is rod-shaped ( 0.6 by 1.5 to 2.0 $\mu \mathrm{m}$ ), growing in short chains of three to four cells each, and possesses mesosomes and a cell wall of uniform thickness ( 28 to $35 \mathrm{~nm}$ ) that consists of an electrondense outer layer and an inner layer resembling unit-membrane structure. The organism is a facultative anaerobe which reacts negatively in tests for cytochrome oxidase, catalase, "gelatinase," urease, tryptophanase, and nitrate and disulfide reductase activities. No dextran or levan is produced from sucrose. It produces L-(+)-lactic acid but not D-(-)-lactic acid from glucose and sucrose fermentation, acetylmethylcarbinol, or arginine deaminase. Glucose, sucrose, galactose, maltose, fructose, trehalose, salicin, inulin, and cellobiose, but not gluconate, lactose, mannose, mannitol, sorbitol, melibiose, or raffinose, were utilized as carbon sources. Its chromosome has an average guanine-plus-cytosine content of 32.75 mol\%. Based on these features, the bacterium appears to be a hitherto unrecognized species of the genus Lactobacillus, for which the name Lactobacillus hordniae sp. nov. is proposed. The type strain is HC-1 (= ATCC 29071).
\end{abstract}

The etiological agent of Pierce's disease of grapevines recently was reported to be a grampositive, rod-shaped bacterium (1; J. G. Auger, Ph.D. thesis, University of California, Davis, Calif., 1974). This organism has been recovered from the leafhoppers Hordnia circellata and Draeculacephala minerva (J. G. Auger, Ph.D. thesis), which are well-known vectors of the Pierce's disease agent. Subsequent tests have shown that the bacterium is not the pathogenic agent of Pierce's disease and is commonly associated with infective and noninfective $H$. circellata leafhoppers collected in San Joaquin, Sacramento, and Napa counties, California (20). The bacterium seems to be commonly associated with $H$. circellata but not with $D$. minerva (20; B. A. Latorre, Ph.D. thesis, University of California, Davis, Calif., 1975). Bacteria-like cells observed in diseased vines $(8,10)$ have not yet been cultured in vitro, and all available evidence indicates that they are unrelated to the bacterium associated with $H$. circellata. The characteristics and taxonomy of this leafhopper orga- nism are presented in this report. Portions of this work appeared in a preliminary report (13).

\section{MATERIALS AND METHODS}

Bacterial strains. Strain PD-A was obtained from J. A. Auger, University of California, Davis, Calif., who isolated the bacterium from $D$. minerva leafhoppers after feeding them on infected grapevines. Strains HC-6 and HC-MP-33 were obtained from A. Purcell, University of California, Berkeley, Calif., who isolated them from $H$. circellata collected in Napa and Alameda counties, California. All other strains were obtained from $H$. circellata collected in Northern California (Table 1).

Media. The leafhopper-associated bacteria were cultured on medium 523 containing $1 \%$ sucrose, $0.8 \%$ casein hydrolysate, $0.4 \%$ yeast extract, $0.3 \% \mathrm{KH}_{2} \mathrm{PO}_{4}$, $0.03 \% \mathrm{MgSO}_{4} \cdot 7 \mathrm{H}_{2} \mathrm{O}$, and $1.5 \%$ agar (Difco) (12). Other media that were used for test purposes included MacConkey agar (Difco), SS agar (Difco), medium D1, medium D2, and modified D1 (12), Gasser's lactobacilli medium (6), Rogosa's medium (23), potato dextrose agar (Difco), medium 523 containing $0.5 \%$ sodium thioglycollate, and medium YGC (1\% yeast extract [Difco], $2 \%$ glucose, $2 \% \mathrm{CaCO}_{3}$ [Mallinckrodt, 
ultrafine]). All media contained 1.5\% agar (Difco) unless specified otherwise. Bacteria were incubated at $30^{\circ} \mathrm{C}$ for 1 to 5 days depending on the medium. Pure cultures were examined by electron microscopy either as whole cells or sectioned cells (see below).

Electron microscopy. Cells were grown in medium 523 , and samples were withdrawn after 12,120 , and $240 \mathrm{~h}$ of incubation at room temperature. Cells of each sample were washed twice in $50 \mathrm{mM}$ potassium phosphate buffer, $\mathrm{pH} 6.8$, and then twice with distilled water. The cells were then fixed for $18 \mathrm{~h}$ at room temperature in $2 \%$ freshly prepared osmium tetraoxide, dehydrated in acetone, and embedded in epoxy resin (27). Ultrathin sections were made of each specimen with a Porter-Blum ultramicrotome. The sections were stained with saturated uranyl acetate in $50 \%$ ethanol for $2 \mathrm{~h}$, washed with double-distilled water, and post-stained for 5 to $10 \mathrm{~min}$ with $2.66 \%$ alkaline lead citrate, pH 12 . Sections were mounted on copper grids and initially examined with an RCA electron microscope, model EMU III, and then with an AE1 electron microscope, model 801, for high-resolution microscopy.

Physiological and biochemical properties. Standard qualitative biochemical tests were performed as described elsewhere (9), and, whenever possible, Pathotec test strips (Warner-Lambert) and Enterotubes (Hoffman-LaRoche) were also used in addition to standard tube tests for enzymatic activity such as cytochrome oxidase, catalase, nitrate reductase, arginine deaminase (18), urease, sulfate reductase, tryptophanase, and the enzymes (gelatinases) involved in gelatin liquefaction and mixed acid fermentative pathways as described by Holding and Collee (9).

Carbohydrate utilization. Each carbohydrate used was sterilized by filtration through a $0.22-\mu \mathrm{m}$ pore-size filter in a membrane filtering apparatus (Millipore Corp., Bedford, Mass.) and added to a basal medium containing $0.2 \%$ casein enzymatic hydrolysate (Calbiochem, La Jolla, Calif.), $0.5 \% \mathrm{NaCl}, 0.2 \%$ $\mathrm{K}_{2} \mathrm{HPO}_{4}$, pH 7.8 , and $0.003 \%$ bromothymol blue to give a final carbohydrate concentration of $1 \%(\mathrm{wt} / \mathrm{vol})$, with the exception of ribose and trehalose, which were $0.1 \%$ and $0.5 \%$ in final concentration, respectively. Tubes containing the agar medium were stab inoculated, sealed with 1 to $2 \mathrm{ml}$ of a sterile paraffin-petro- latum mixture (1:6, wt/wt), and incubated for $48 \mathrm{~h}$ at $30^{\circ} \mathrm{C}$. Positive utilization was indicated by surface growth and acid production.

Determination of lactic acid end product. Cultures were grown for $37 \mathrm{~h}$ at $30^{\circ} \mathrm{C}$ in medium 523 containing $1 \%$ glucose instead of sucrose. During this time, culture samples were withdrawn periodically, and the $\mathrm{pH}$ and extent of bacterial growth were determined for each sample by the use of a Radiometer digital $\mathrm{pH}$ meter and by turbidimetry. The samples were then deproteinized by titration with $\mathrm{NaOH}$ to $\mathrm{pH} 7.6$ in the presence of $2.5 \%$ (wt/vol) zinc sulfate $(2,26)$. The resulting precipitate was removed by centrifugation $(12,000 \times g, 5 \mathrm{~min})$, and the supernatant was carefully collected for analysis of lactate. Rabbit muscle lactic dehydrogenase (EC 1.1.1.27) (Worthington Biochemicals Corp., Freehold, N.J.) specific for L-(+)-lactate and Lactobacillus leishmannii D-(-)lactate dehydrogenase (EC 1.1.1.28) (Boehringer Mannheim Corp., New York, N.Y.) were used for the lactate analyses. The assay mixture consisted of 60 $\mu \mathrm{g}$ of enzyme per $\mathrm{ml}$ in $2 \mathrm{ml}$ of hydrazine-glycine buffer $(7.5 \%$ glycine, $5.2 \%$ hydrazine sulfate, $0.2 \%$ sodium ethylenediamine-tetraacetate [EDTA] and $4 \%$

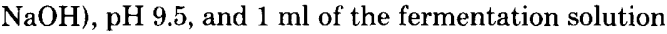
and 5.6 $\mu \mathrm{M}$ nicotinamide adenine dinucleotide were added. Sterile broth media containing known amounts of either $\mathrm{L}-(+)$ - or $\mathrm{D}-(-)$-lithium lactate again were employed as controls. The above-mentioned enzymes showed specificities for their respective substrates. Substrate-utilization rates were monitored at $340 \mathrm{~nm}$ in a Beckman ACTA III recording spectrophotometer by following the reduction of nicotinamide adenine dinucleotide.

Dextran production. Cultures were plated on medium 523 agar containing 1\% (wt/vol) sucrose. The plates were incubated at room temperature, and after $24 \mathrm{~h}$ they were periodically examined for dextran by the appearance of mucilagenous colonies.

Minimal and maximal temperatures for growth. Cultures were streaked on medium 523 agar slopes and incubated for 4 to 5 days at 10,15, 20, 25, 30,37 , and $45^{\circ} \mathrm{C}$ temperatures as specified in the text. L. plantarum ATCC 14917 and L. salivarius ATCC 11741 were grown in parallel cultures for comparative controls. The results were recorded as positive or

TABLE 1. List of the bacterial strains associated with Pierce's disease leafhopper vectors and used in this study

\begin{tabular}{|c|c|c|c|c|}
\hline Strain & Isolated from: & Place and date & Author & Reference $^{t}$ \\
\hline PD-A & Infected grapes $^{b}$ & Davis, Fall 73 & J. A. Auger & A \\
\hline HC-1 & Hordnia circellata & Napa, Oct. 74 & B. Latorre-Guzmán & B \\
\hline HC-2 & Hordnia circellata & Napa, Oct. 74 & B. Latorre-Guzmán & B \\
\hline $\mathrm{HC}-3$ & Hordnia circellata & Napa, Oct. 74 & B. Latorre-Guzmán & $\mathrm{B}$ \\
\hline $\mathrm{HC}-4$ & Hordnia circellata & Napa, Oct. 74 & B. Latorre-Guzmán & B \\
\hline $\mathrm{HC}-5$ & Hordnia circellata & Napa, Oct. 74 & B. Latorre-Guzmán & $\mathrm{B}$ \\
\hline HC-6 & Hordnia circellata & Berkeley, Jan. 75 & A. Purcell et al. & 20 \\
\hline HC-MP-33 & Hordnia circellata & Napa, Fall 74 & A. Purcell et al. & 20 \\
\hline HC-7 & Hordnia circellata & Napa, July 75 & B. Latorre-Guzmán & $\mathrm{B}$ \\
\hline
\end{tabular}

${ }^{a}$ A, J. G. Auger, Ph.D. thesis, University of California, Davis, Calif., 1974; B, B. A. Latorre, Ph.D. thesis, University of California, Davis, Calif., 1975.

${ }^{b}$ Isolated from Draeculacephala minerva leafhoppers after feeding them on infected grape plants (J. G. Auger, Ph.D. thesis). 
negative based on visual observation of growth.

Thermal death point. Cultures were grown in 10 $\mathrm{ml}$ of medium 523 for $24 \mathrm{~h}$, and the cells were washed and suspended in $15 \mathrm{ml}$ of distilled water. The suspensions were incubated at various temperatures for 10 min, and $50-\mu \mathrm{l}$ samples of each cell suspension were plated on medium 523 agar. The effect of temperature upon the viability of the cell population was measured by colony counts.

Preparation of DNA for guanine-cytosine content determination. Except as noted, deoxyribonucleic acid (DNA) was isolated by the combined procedures described elsewhere $(15,24)$. Cells were grown in medium 523 containing $7 \mathrm{~g}$ instead of $3 \mathrm{~g}$ of $\mathrm{K}_{2} \mathrm{HPO}_{4}$ per liter. Usually about $15 \mathrm{~g}$ (wet weight) of cells was collected by centrifugation, washed twice in $50 \mathrm{mM}$ sodium phosphate buffer, $\mathrm{pH} 7.0$, containing $10 \mathrm{mM}$ EDTA, and resuspended in the same buffer. Freshly prepared lysozyme $(250 \mu \mathrm{g} / \mathrm{ml})$ (Sigma Chemical Co., St. Louis, Mo.) was added, and the cell suspension was incubated for $2 \mathrm{~h}$ at $37^{\circ} \mathrm{C}$ and then with Pronase (predigested for $25 \mathrm{~min}$ ) (Calbiochem) $(50 \mu \mathrm{g} / \mathrm{ml})$ for $1 \mathrm{~h}$ at $37^{\circ} \mathrm{C}$. The cells were lysed with sodium dodecyl sulfate ( $1 \%$ final concentration) and incubated for 1 to $2 \mathrm{~h}$ at $37^{\circ} \mathrm{C}$. The mixture was then deproteinized with chloroform- $n$-butanol $(4: 1, \mathrm{vol} / \mathrm{vol})$, and the aqueous phase, collected by centrifugation at 10,000 $\times g$, was emulsified with two volumes of $80 \%$ phenol ( $\mathrm{pH}$ 7.0). The emulsion was broken by centrifugation $(12,000 \times g, 10 \mathrm{~min})$, and the DNA was precipitated from the aqueous phase with two volumes of ice-cold $95 \%$ ethanol. The DNA was collected by spooling on a glass rod and was then dissolved in $0.1 \times \mathrm{SSC}(0.015$ $\mathrm{M} \mathrm{NaCl}-0.0015 \mathrm{M}$ trisodium citrate, $\mathrm{pH}$ 7.0) containing $10 \mathrm{mM}$ EDTA. The DNA solution was subsequently dialyzed overnight against $0.1 \times \mathrm{SSC}$ and was then treated with deoxyribonuclease-free pancreatic ribonuclease A (Worthington Biochemicals Corp.) (50 $\mu \mathrm{g} / \mathrm{ml}$ ) for 2 to $3 \mathrm{~h}$ at $37^{\circ} \mathrm{C}$ followed by Pronase (predigested for $25 \mathrm{~min})$ treatment $(200 \mu \mathrm{g} / \mathrm{ml})$ for 2 $\mathrm{h}$ at $37^{\circ} \mathrm{C}$. The DNA solution was repeatedly extracted with chloroform- $n$-butanol until no white precipitate was obtained at the interphase. The DNA was precipitated from the aqueous phase with ice-cold isopropanol, redissolved in $0.1 \times \mathrm{SSC}$, and stored at $4^{\circ} \mathrm{C}$ over a few drops of chloroform.

The freshly prepared DNA samples were dialyzed overnight against appropriate buffers. For base analysis by the buoyant-density method (14), the DNA solution was equilibrated with $0.02 \mathrm{M}$ tris(hydroxymethyl) aminomethane-chloride buffer (pH 8.5). Optical-grade CsCl (Merck, Sharp \& Dohme, Rahway, N.J.) was used, and Escherichia coli AB295 DNA served as an internal standard. A Beckman analytical ultracentrifuge equipped with an autoscanner and digital integrator was used.

For analysis by the thermal denaturation method (16), the DNA solution was equilibrated with $0.1 \times$ SSC. DNA melting was measured continuously at 260 $\mathrm{nm}$ in a Beckman ACTA III recording spectrophotometer equipped with a matched pair of cuvettes electrically heated with a linear-temperature programmer. The absorbancy and temperature changes were measured simultaneously on a Honeywell $\mathrm{x}-\mathrm{y}$ recorder. DNA base compositions were obtained from the mean buoyant densities in $\mathrm{CsCl}$ using the equation guanine plus cytosine $(\mathrm{G}+\mathrm{C})=10.309(\rho-1.6620)(7)$ and from the mean $T_{m}$ by the equation $\mathrm{G}+\mathrm{C}=\left(T_{m}-53.9\right)$ $\times 2.44(17)$.

\section{RESULTS}

Insect carrier and its distribution in Northern California. A gram-positive, rodshaped bacterium, herein referred to as "leafhopper bacterium," was isolated consistently from $H$. circellata but not from any specimens of D. minerva collected at the same time that $H$. circellata was collected in Napa, Butte, and San Joaquin counties (Table 2). Auger (Ph.D thesis) reported isolating the same bacterium from $D$. minerva in previous years, but in no

TABLE 2. Results on the isolation of the leafhopper bacterium from host leafhoppers collected in 1974 to 1975 and assayed on medium 523

\begin{tabular}{|c|c|c|c|c|}
\hline Leafhopper species & Place and date of collection & Host plant & $\begin{array}{l}\text { No. of in- } \\
\text { sects col- } \\
\text { lected }\end{array}$ & $\begin{array}{c}\text { No. of insects } \\
\text { harboring } \\
\text { leafhopper } \\
\text { bacterium }\end{array}$ \\
\hline Hordnia circellata & Spring Hills, Napa County; July 74 & Grape & 22 & $0(0)^{a}$ \\
\hline H. circellata & Yountville, Napa County; Oct. 74 & Grape & 13 & $1(7.7)$ \\
\hline H. circellata & Yountville, Napa County; Oct. 74 & Natural hosts $^{b}$ & 68 & $52(76.5)$ \\
\hline H. circellata & Yountville, Napa County; Oct. 74 & Natural hosts & 116 & $56(48.3)$ \\
\hline H. circellata & Yountville, Napa County; June 75 & Natural hosts & 30 & $23(77.0)$ \\
\hline H. circellata .......... & Yountville, Napa County; May 75 & Natural hosts & 27 & $8(30.0)$ \\
\hline Draeculacephala minerva & Chico, Butte County; Oct. 74 & Natural hosts & 15 & $0(0)$ \\
\hline D. minerva . . . . . . . & Napa, Napa County; Aug. 75 & Natural hosts & 10 & $0(0)$ \\
\hline D. minerva & Napa, Napa County; Sept. 75 & Natural hosts & 74 & $0(0)$ \\
\hline D. minerva & Manteca, San Joaquin County; Sept. 75 & Bermuda grass & 66 & $0(0)$ \\
\hline D. minerva & Manteca, San Joaquin County; Oct. 75 & Bermuda grass & 70 & $0(0)$ \\
\hline D. minerva & Manteca, San Joaquin County; Oct. 75 & Grape & 57 & $0(0)$ \\
\hline
\end{tabular}

${ }^{a}$ Figures in parentheses are percentages.

${ }^{b}$ Willow, mexican tea, wild grapes, bermuda grass, and other plants found near vineyards.

' $T$ These leafhoppers were fed on a diseased leaf for $24 \mathrm{~h}$ before being plated on 523 agar at $30^{\circ} \mathrm{C}$ for over 3 days. 


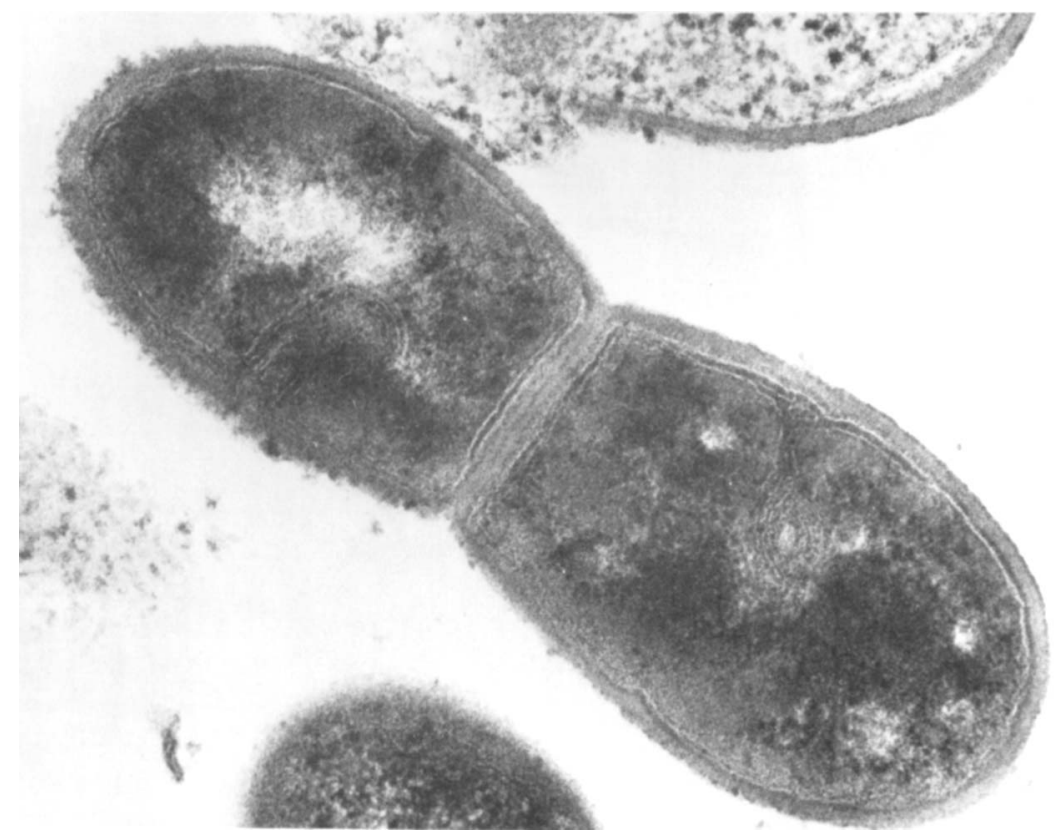

FIG. 1. Ultrastructure of a cell of leafhopper bacterium strain HC-1 undergoing binary fission. Magnification, $\times 81,000$.

instance was this bacterium isolated in our screenings, which is in agreement with our previous reported experience (20).

A description of the $H$. circellata organism follows.

Morphology. The leafhopper bacterium is rod-shaped, averaging $0.6 \mu \mathrm{m}$ in width and 1.5 to $2.0 \mu \mathrm{m}$ in length, gram positive, nonmotile, and nonsporeforming. Ultrathin sections of the leafhopper bacterium revealed a rod-shaped cell with a thick, smooth, uniform cell wall (Fig. 1). The cell wall is composed of an outer layer, an inner electron-dense layer, and the cytoplasmic membrane. A low-density material is seen in the cytoplasm of the cell. At high resolution, the outer layer is seen as a single electron-dense material composed of an inner layer resembling a unit-membrane structure consisting of two thin electron-dense layers sandwiching a lowdensity material (Fig. 1). The overall cell wall complex is about 28 to $35 \mathrm{~nm}$ in thickness in cells of 5-day-old cultures.

Easily distinguishable are the ribosomes scattered in the cytoplasm, large mesosomes that are found most often in gram-positive bacteria (25), and stringy electron-dense material, presumably DNA of the genome. The mesosomes appear to be the result of the invagination of the inner cytoplasmic membrane and are also observed next to points of fission in the dividing bacteria. Cells usually occur as short chains com- posed of three to four cells each. This is particularly evident in 24-h-old cultures. A large number of cells in 5- and 10-day-old cultures were completely lysed; in these instances, the cell walls appeared completely disrupted and the cytoplasmic contents were dispersed (Fig. 2).

Growth characteristics. The leafhopper bacterium was tested on various media, and good growth was obtained on liquid or solid medium 523. Rogosa's MRS and Gasser's general medium for lactobacilli also supported the growth of this organism. On 523 agar, the colonies were smooth, glistening white or grayish white in appearance, 0.4 to $0.5 \mathrm{~mm}$ in diameter, with entire margins (Fig. 3), and acid was produced as judged by the clearing of $\mathrm{CaCO}_{3}$ in 523 agar medium. Viability of cultures is lost after 7 days of incubation at room temperature. Viability may be extended a few more days by stab inoculation or liquid storage at $4^{\circ} \mathrm{C}$. The loss of viability was accompanied by a change in Gram-staining reactions. Old cultures (over 5 days old) no longer consistently gave a grampositive reaction, a property also found in lactobacilli (21).

Temperature and $\mathbf{p H}$ relationships. Six strains that were tested grew between 15 and $37^{\circ} \mathrm{C}$ with optimum growth at $30^{\circ} \mathrm{C}$ ('Table 3). Only strain $\mathrm{HC}-4$ showed some growth at $10^{\circ} \mathrm{C}$. No growth was observed at 9 or at $45^{\circ} \mathrm{C}$. No cells survived at $48^{\circ} \mathrm{C}$ for $10 \mathrm{~min}$ in $15 \mathrm{ml}$ of 


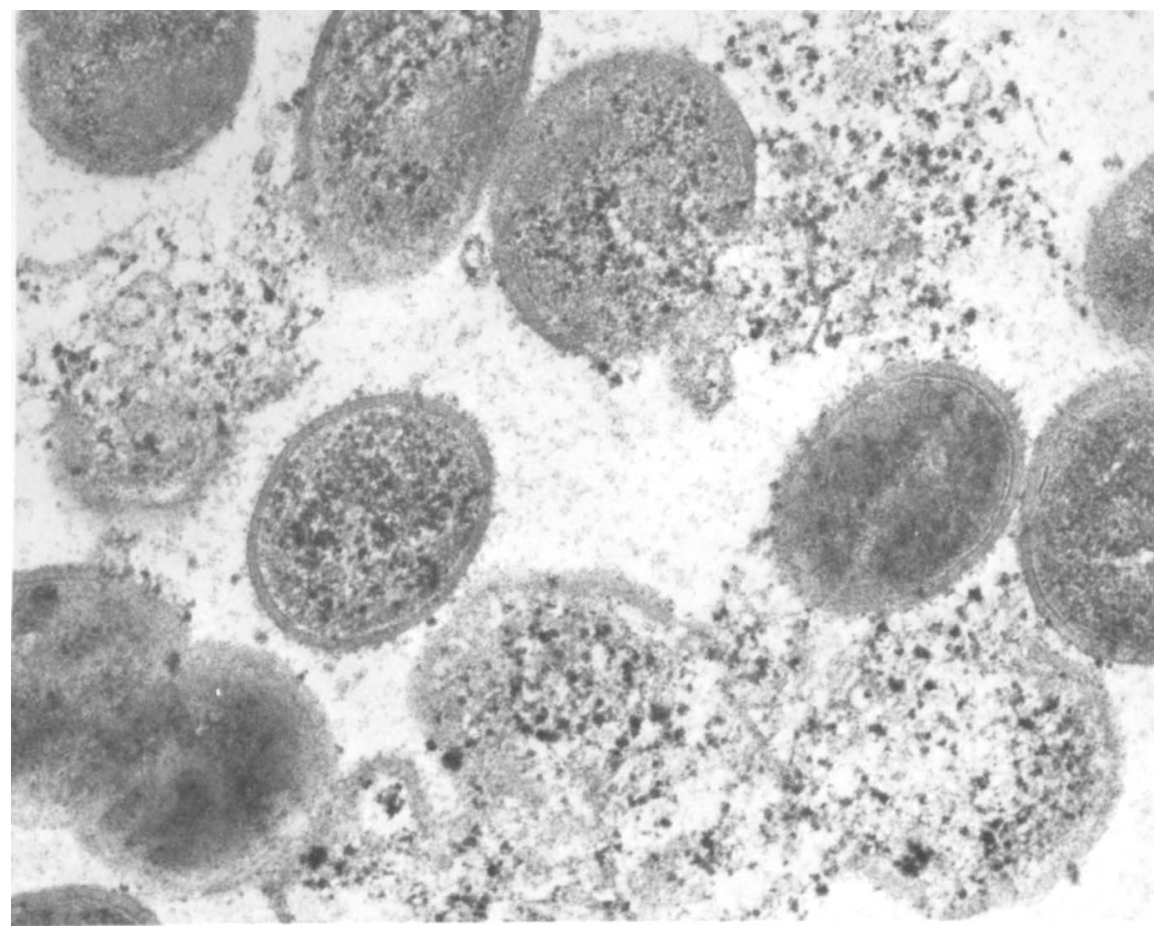

FIG. 2. Lysis of leafhopper bacterium strain HC-1 after 5-day growth in medium 523 at $30^{\circ}$ C. Magnification, $\times 51,000$

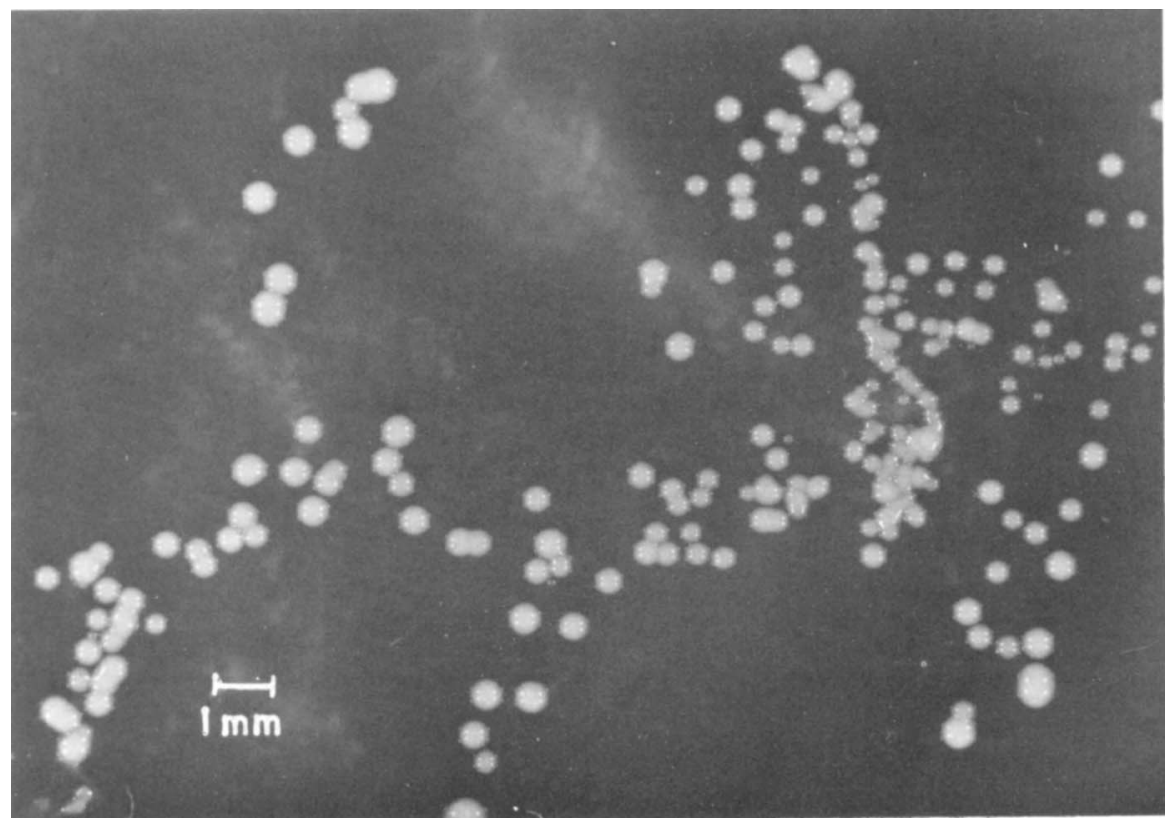

FIG. 3. Colony morphology of leafhopper bacterium strain $\mathrm{HC}-1$ on medium 523 after $48 \mathrm{~h}$ at $30^{\circ} \mathrm{C}$. 
TABLE 3. Effect of temperature on growth of different strains of the leafhopper bacterium and of Lactobacillus reference strains"

\begin{tabular}{|c|c|c|c|c|c|c|}
\hline \multirow{2}{*}{ Strain } & \multicolumn{6}{|c|}{ Growth at: } \\
\hline & $10^{\circ} \mathrm{C}$ & $15^{\circ} \mathrm{C}$ & $20^{\circ} \mathrm{C}$ & $30^{\circ} \mathrm{C}$ & $37^{\circ} \mathrm{C}$ & $45^{\circ} \mathrm{C}$ \\
\hline PD-A & - & + & +++ & $++t$ & + & - \\
\hline HC-1 & - & + & +++ & +++ & - & - \\
\hline $\mathrm{HC}-2$ & - & + & +++ & +++ & + & - \\
\hline $\mathrm{HC}-4$ & + & + & +++ & +++ & + & - \\
\hline $\mathrm{HC}-5$ & - & + & +++ & +++ & + & - \\
\hline HC-MP-33 & - & + & +++ & +++ & + & - \\
\hline Lactobacillus salivarius ATCC 11741 & - & - & - & +++ & +++ & +++ \\
\hline Lactobacillus plantarum ATCC 14917 & - & - & + & + & +++ & + \\
\hline
\end{tabular}

"Symbols: -, no growth; +, poor growth; +++, good growth.

TABIE 4. L-(+)-Lactic acid production by strain $H C-1$ during glucose fermentation as a function of time

\begin{tabular}{|c|c|c|c|c|}
\hline \multirow[t]{2}{*}{$\begin{array}{l}\text { Incubation } \\
\text { time (h) }\end{array}$} & \multirow[t]{2}{*}{$\begin{array}{c}\text { Cells/ml } \\
\left(\times 10^{8}\right)\end{array}$} & \multirow[t]{2}{*}{$\begin{array}{l}\mathrm{pH} \text { of cul- } \\
\text { ture }\end{array}$} & \multicolumn{2}{|c|}{$\begin{array}{l}\text { Lactic acid produced } \\
(\mu \mathrm{M} \text { lactate } / \mu \mathrm{M} \\
\text { glucose })\end{array}$} \\
\hline & & & $\mathrm{L}-(+)$ & D)-(-) \\
\hline 0 & 0 & 7.2 & 0 & 0.00 \\
\hline 2 & 0.9 & 6.8 & 0.05 & 0.00 \\
\hline 4 & 2.15 & 6.7 & 0.12 & 0.00 \\
\hline 6 & 5.95 & 6.3 & 0.36 & 0.00 \\
\hline 7 & 8.70 & 5.7 & 0.56 & 0.00 \\
\hline 8 & 9.70 & 5.2 & 0.75 & 0.00 \\
\hline 9 & 12.30 & 5.0 & 1.12 & 0.00 \\
\hline 11 & 14.30 & 4.8 & 1.35 & 0.00 \\
\hline 13 & 13.10 & 4.6 & 1.34 & 0.00 \\
\hline 31 & 14.80 & 4.5 & 1.71 & 0.00 \\
\hline 37 & 17.70 & 4.4 & 2.15 & 0.01 \\
\hline
\end{tabular}

sterile distilled water. A broad $\mathrm{pH}$ range $(\mathrm{pH}$ 5.0 to 8.5$)$ permits the growth of this bacterium; the $\mathrm{pH}$ for optimum growth in medium 523 is 6.5. No growth was observed at $\mathrm{pH} 4.5$ and $\mathrm{pH}$ 9.0. The organism is stable in the freeze-dried state.

Physiological characteristics. The leafhopper bacterium is facultatively anaerobic and reacts negatively in tests for the presence of cytochrome oxidase, catalase, gelatinase, urease, tryptophanase, and nitrate reductase activities. Hydrogen sulfide is not produced from either peptone or broth containing cysteine. The organism produces $\mathrm{L}-(+)$-lactic acid abundantly during glucose fermentation with a concomitant drop in $\mathrm{pH}$ (Table 4). No D-(-)-lactate was observed. Acetylmethylcarbinol is produced from glucose, as judged by the positive VogesProskauer reaction, and arginine deaminase activity was positive after $24 \mathrm{~h}$. No dextran or levan production from sucrose was observed.

Carbohydrate utilization. Table 5 shows the spectrum of sugars utilized by all six strains of the leafhopper bacterium. There were a num- ber of carbohydrates not utilized, and no growth was observed when gluconate or lactate salts were used as sole carbon sources by these strains. Growth occurred in litmus milk only when it was supplemented with $1 \%$ (wt/vol) glucose; an acid reaction was observed after 3 days of incubation at $30^{\circ} \mathrm{C}$.

DNA base composition of the leafhopper bacterium. The DNA of the leafhopper bacterium melted at a relatively low temperature $\left(T_{m}\right.$ $=66.8^{\circ} \mathrm{C}$ in $0.1 \times \mathrm{SSC}$ ) (Fig. 4). This is equivalent to DNA with a $\mathrm{G}+\mathrm{C}$ content of $31.9 \mathrm{~mol} \%$. The $\mathrm{G}+\mathrm{C}$ content obtained by buoyant-density measurements gave an average density of 1.6946 $\mathrm{g} / \mathrm{ml}$, which is equivalent to DNA with a $\mathrm{G}+\mathrm{C}$ content of $33.6 \mathrm{~mol} \%$. The average $\mathrm{G}+\mathrm{C}$ content based on these measurements is $32.75 \mathrm{~mol} \%$. This is much lower than the $\mathrm{G}+\mathrm{C}$ content (in moles percent) of the following gram-positive phytopathogenic bacteria that were measured in the same way: Corynebacterium insidiosum (71.82); C. sepedonicum (62.17); C. poinsettiae (72.24); C. michiganense (74.83); C. flaccumfaciens (69.77); and C. fascians (64.99).

\section{DISCUSSION}

The morphological and physiological characteristics of a bacterium commonly associated with $H$. circellata indicate that the bacterium belongs to the family Lactobacillaceae (21): the organism is a gram-positive, facultatively anaerobic, nonmotile, nonsporeforming, short rodshaped (but not coccoid) cell that grows in short chains, produces L-(+)-lactic acid abundantly from carbohydrates, and does not produce cytochrome oxidase, catalase, or nitrate and disulfide reductases. These features are typical for lactobacilli $(11,19,21,22)$ and are not confused with the features of members of the other genera of the family-Listeria, Erysipelothrix, and Caryophanon-which are coccoidal, have a tendency to form long filaments, and are aerobes, respectively (21). However, the description of 
TABLE 5. Utilization of carbohydrates as sole energy sources"

\begin{tabular}{|c|c|c|c|c|c|c|}
\hline \multirow{2}{*}{ 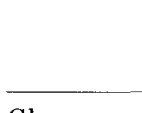 } & \multicolumn{6}{|c|}{ Utilization by strain: } \\
\hline & PD-A & $\mathrm{HC}-1$ & $\mathrm{HC}-4$ & $\mathrm{HC}-5$ & HC-MP-33 & $\mathrm{HC}-6$ \\
\hline Glucose & $t++$ & +++ & $t+t$ & +++ & +++ & +++ \\
\hline Fructose & + & + & + & + & + & + \\
\hline Galactose & +++ & +++ & +++ & +++ & +++ & +++ \\
\hline Maltose & + & + & + & +++ & +++ & ND \\
\hline Lactose & - & - & - & - & - & ND \\
\hline Sucrose & +++ & +++ & +++ & +++ & +++ & +++ \\
\hline Xylose & - & - & - & - & - & - \\
\hline Arabinose & - & - & - & - & - & - \\
\hline Rhamnose & - & - & - & - & - & - \\
\hline Ribose .. & - & - & - & - & - & - \\
\hline Inulin & +++ & +++ & +++ & +++ & +++ & $++t$ \\
\hline Raffinose & - & - & - & - & - & - \\
\hline Mannose & - & - & - & - & - & ND \\
\hline Trehalose & +++ & + & + & + & + & + \\
\hline Salicin ... & ++ & +++ & +++ & +++ & +++ & + \\
\hline Cellobiose & ++ & ++ & ++ & ++ & ++ & - \\
\hline Melibiose & - & - & - & - & - & - \\
\hline Glycerol . & - & - & - & - & - & - \\
\hline Sorbitol & - & - & - & - & - & - \\
\hline Inositol & - & - & - & - & - & - \\
\hline Mannitol & - & - & - & - & - & - \\
\hline Gluconate & - & - & - & - & - & - \\
\hline Lactate . & - & - & - & - & - & - \\
\hline Starch & - & ND & ND & ND & ND & ND \\
\hline
\end{tabular}

${ }^{a}$ Symbols: -, no utilization at $30^{\circ} \mathrm{C} ;+$, poor utilization; ++ , moderate; +++ , good. $\mathrm{ND}$, not determined.

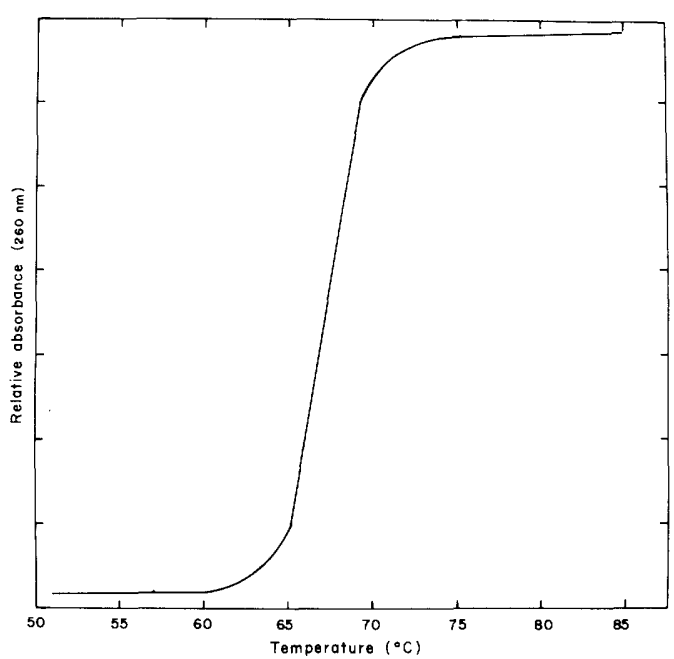

FIG. 4. Thermal denaturation of leafhopper bacterium strain HC-1. DNA in $0.1 \times$ SSC. The $T_{m}$ was $66.8^{\circ} \mathrm{C}$.

the organism from $H$. circellata does not easily correlate with any previously described lactobacillus. Because the organism is strictly homofermentative and produces stoichiometric amounts of $\mathrm{L}-(+)$-lactic acid from glucose (Table 4 ), it should be regarded as belonging to Lacto- bacillus salivarius (21). Indeed, the cell size and the DNA characteristics (melting point and $\mathrm{G}+\mathrm{C}$ content) of the leafhopper bacterium and of $L$. salivarius are essentially the same (Table 6). However, L. salivarius differs from the leafhopper organism in several ways: $L$. salivarius exhibits rough colony morphology rather than smooth on the same media, and it does not grow well at $20^{\circ} \mathrm{C}$ but does grow well at $45^{\circ} \mathrm{C}$. On the other hand, the leafhopper organism grows well at $15^{\circ} \mathrm{C}$ and $20^{\circ} \mathrm{C}$ but not at $45^{\circ} \mathrm{C}$ (Table 3). Furthermore, the carbohydrate-utilization profiles of the two organisms are dissimilar: $L$. salivarius will not utilize cellobiose or sorbitol but will use lactose, mannose, and mannitol (Table 7). The carbohydrate-utilization pattern of the other closely related lactobacilli are also given in Table 7 , but none of these has any closer resemblance to the leafhopper organism described here than does $L$. salivarius. Finally, the habitat of the leafhopper organism seems to be restricted to the insect body of $H$. circellata, whereas the lactobacilli indicated in Table 6 (L. bulgaricus, L. jugurti, L. helveticus) are mainly associated with dairy products or are found in human saliva or the digestive tract of certain animals ( $L$. salivarius and $L$. acidophilus).

The new organism described here also does 
TABLE 6. Characteristics that differentiate the leafhopper bacterium from other Lactobacillus species

\begin{tabular}{|c|c|c|c|c|c|c|c|c|c|}
\hline \multirow{2}{*}{ Organism } & \multicolumn{2}{|c|}{$\begin{array}{l}\text { Mol } \% \mathrm{G}+\mathrm{C} \\
\text { from: }\end{array}$} & \multirow{2}{*}{ Cell dimensions $(\mu \mathrm{m})$} & \multirow{2}{*}{$\begin{array}{l}\text { Colony } \\
\text { type }^{a}\end{array}$} & \multirow{2}{*}{\multicolumn{2}{|c|}{$\begin{array}{l}\text { Stereo- } \\
\text { isomer of Gas from } \\
\text { lactic acid glucose } \\
\text { produced }\end{array}$}} & \multicolumn{2}{|c|}{ Growth at: } & \multirow{2}{*}{ Source } \\
\hline & $T_{m}$ & $\begin{array}{l}\text { Buoy- } \\
\text { ant den- } \\
\text { sity }\end{array}$ & & & & & $15^{\circ} \mathrm{C}$ & $45^{\circ} \mathrm{C}$ & \\
\hline \multirow{2}{*}{$\begin{array}{l}\text { Leafhopper bacte- } \\
\text { rium (strain HC-1) } \\
\text { Lactobacillus aci- } \\
\text { dophilus }\end{array}$} & 31.9 & 33.6 & $0.5-0.6 \times 1.5-2.0$ & $\mathrm{~S}$ & $\mathrm{~L}(+)$ & - & + & - & \multirow{2}{*}{$\begin{array}{l}\text { Hordnia circellata } \\
\text { Intestinal tracts of an- } \\
\text { imals }\end{array}$} \\
\hline & $50.2^{b}$ & $36.6^{\circ}$ & $0.6-0.9 \times 1.5-6.0$ & $\mathbf{R}$ & DI & - & - & + & \\
\hline L. bulgaricus ..... & $38.3^{b}$ & $50.3^{\circ}$ & & $\mathrm{R}$ & $\mathrm{D}(-)$ & - & - & + & Dairy products \\
\hline L. helveticus & $38.3^{b}$ & $39.3^{\prime}$ & $0.6-1.0 \times 2.6$ & $\mathrm{~S}$ & $\mathrm{DL}$ & - & - & + & Dairy products \\
\hline L. jugurtid & $37.7^{h}$ & $39.0^{\circ}$ & & $\mathbf{S}$ & DL & - & - & + & Dairy products \\
\hline L. salivarius & 32.4 & $34.7^{\circ}$ & $0.6-0.9 \times 1.5-5.0$ & $\mathbf{R}$ & $\mathrm{L}(+)$ & - & - & + & $\begin{array}{l}\text { Human saliva and in- } \\
\text { testinal tracts of } \\
\text { some animals }\end{array}$ \\
\hline
\end{tabular}

"Abbreviations: $\mathrm{R}$, rough; $\mathrm{S}$, smooth.

${ }^{h}$ Data from Miller et al. (17).

"Data from Gasser and Mandel (7).

"Synonym of L. helveticus (see references 2 and 23).

TABLE 7. Carbohydrate utilization by the leafhopper bacterium compared with results reported for Lactobacillus acidophilus, L. bulgaricus, L. helveticus, and L. salivarius ${ }^{a}$

\begin{tabular}{|c|c|c|c|c|c|}
\hline Carbohydrate & $\begin{array}{c}\text { Leafhopper bac- } \\
\text { terium (strain } \\
\text { HC-1) }\end{array}$ & L. acidophilus & L. bulgaricus & L. helveticus & L. salivarius \\
\hline$\ldots \ldots \ldots \ldots$ & + & + & + & + & + \\
\hline Sucrose & + & + & - & - & + \\
\hline$\ldots \ldots \ldots \ldots \ldots$ & + & + & + & + & + \\
\hline$\ldots \ldots \ldots$ & + & + & - & + & + \\
\hline$\ldots \ldots \ldots \ldots \ldots \ldots$ & + & + & + & - & + \\
\hline$\ldots \ldots \ldots \ldots \ldots \ldots$ & + & + & - & \pm & + \\
\hline Salicin ... & + & + & - & - & \pm \\
\hline$\ldots \ldots \ldots \ldots \ldots \ldots$ & + & + & - & - & - \\
\hline Lactose . . & - & + & + & + & + \\
\hline Mannose & - & + & - & - & + \\
\hline Mannitol . . . . . . . . . . . & - & - & - & - & + \\
\hline Sorbitol $\ldots \ldots \ldots \ldots \ldots \ldots$ & - & - & - & - & - \\
\hline Melibiose $\ldots \ldots \ldots \ldots \ldots \ldots$ & - & \pm & - & - & + \\
\hline Raffinose .... & - & \pm & - & - & + \\
\hline
\end{tabular}

${ }^{a}$ Data from reference 21. Symbols: + , positive reaction; - , negative reaction; \pm , variable reaction depending on the strain.

not closely resemble the lactic acid bacteria of the family Streptococcaceae. The genera of the latter family produce DL-lactic acid (Pediococcus), show poor anaerobic growth (Aerococcus and Gemella), are heterofermentative (Leuconostoc), or exhibit definite coccoidal, or at the most ovoidal, cell morphology (Streptococcus and Pediococcus). One final possibility for the classification of the leafhopper bacterium might be as a member of the rather ill-defined genus Microbacterium. However, the species of this genus only weakly produce lactic acid, are catalase positive, and survive at relatively high temperatures $\left(72^{\circ} \mathrm{C}\right.$ for $\left.15 \mathrm{~min}\right)$ (21). Microbacteria have been found associated chiefly in dairy products or dairy utensils.

Because of the lack of correlation of the fea- tures of the bacterium from $H$. circellata with those of described organisms, it becomes necessary to classify the organism as a new species. The organism fits well the description of Lactobacillus, and thus we regard it as a new species in this genus. The name we propose for this new species is Lactobacillus hordniae (hordni.ae. M.L. fem.n. Hordnia generic name; M.L. gen.noun hordniae of Hordnia circellata, the name of a leafhopper with which this organism is associated). The type strain of $L$. hordniae is HC-1 (=ATCC 29071).

\section{REPRINT REQUESTS}

Address reprint requests to: Dr. C. I. Kado, Department of Plant Pathology, University of California, Davis, CA 95616. 


\section{LITERATURE CITED}

1. Auger, J. G., T. A. Shalla, and C. I. Kado. 1974. Pierce's disease of grapevines: evidence for a bacterial etiology. Science 181: 1375-1377.

2. Dawes, E. A., D. J. McGill, and M. Midgley. 1971. Analysis of fermentation products, p. 53-215. In J. R. Norris and D. W. Ribbons (ed.), Methods in microbiology, vol. 6A. Academic Press, Inc., London.

3. Garvie, E. I. 1960. The genus Leuconostoc and its nomenclature. J. Dairy Res. 27:282-292.

4. Garvie E. I. 1967. Leuconostoc venos sp. nov. J. Gen. Microbiol. 48:431-438.

5. Garvie, E. I. 1975. Some properties of gas forming lactic acid bacteria and their significance in classification, $p$. 339-349. In J. C. Carr, C. V. Cutting, and G. C. Whiting (ed.), Lactic acid bacteria in beverage and food. Academic Press, Inc., London.

6. Gasser, F. 1970. Electrophoretic characterization of the lactic dehydrogenases in the genus Lactobacillus. J. Gen. Microbiol. 62:233-239.

7. Gasser, F., and M. Mandel. 1968. Deoxyribonucleic acid base composition of the genus Lactobacillus. J. Bacteriol. 96:580-588.

8. Goheen, A. C., G. Nyland, and S. K. Lowe. 1973. Association of a rickettsia-like organism with Pierce's disease of grapevines and alfalfa dwarf and heat therapy of the disease in grapevines. Phytopathology 363:341-345.

9. Holding, A. J., and J. G. Collee. 1971. Routine biochemical tests, p. 1-32. In J. R. Norris and D. W. Ribbons (ed.), Methods in microbiology, vol. 6A. Academic Press, Inc., London.

10. Hopkins, D. L., and H. H. Mollenhauer. 1973. Rickettsia-like bacterium associated with Pierce's disease of grapes. Science 179:298-300.

11. Ingram, M. 1975. The lactic acid bacteria. A broad review, p. 1-13. In J. C. Carr, C. V. Cutting, and G. C. Whiting (ed.), Lactic acid bacteria in beverage and food. Academic Press, Inc., London.

12. Kado, C. I., and M. G. Heskett. 1970. Selective media for isolation of Agrobacterium, Corynebacterium, $\mathrm{Er}$. winia, Pseudomonas, and Xanthomonas. Phytopathology 60:969-976.

13. Latorre, B. A., C. I. Kado, A. C. Goheen, and R. E. Kunkee. 1975. Characterization of the bacterium associated with Pierce's disease, p. 67. In R. L. Miller (ed.), Proceedings of the American Phytopathological Society, vol. 2. The American Phytopathological Soci- ety, St. Paul.

14. Mandel, M., C. L. Schildkraut, and J. Marmur. 1968. Use of $\mathrm{CsCl}$ density gradient analysis for determining the guanine plus cytosine content of DNA, p. 184-185. In I. Grossman and K. Moldave (ed.), Methods in enzymology, vol. 2B. Academic Press, Inc., New York.

15. Marmur, J. 1961. A procedure for the isolation of deoxyribonucleic acid from microorganisms. J. Mol. Biol. 3:208-318.

16. Marmur, J., and P. Doty. 1962. Determination of the base composition of deoxyribonucleic acid from its thermal denaturation temperature. J. Mol. Biol. 5:109-118.

17. Miller III, A., W. E. Sandine, and P. R. Elliker. 1970. Deoxyribonucleic acid base composition of lactobacilli determined by thermal denaturation. J. Bacteriol. 102:278-280.

18. Niven, C. F., Jr., K. L. Smiley, and J. M. Sherman. 1942. The hydrolysis of arginine by streptococci. J. Bacteriol. 43:651-660.

19. Orla-Jensen, S. 1919. The lactic acid bacteria. A. F. Host and Sons, Copenhagen.

20. Purcell, A. H., B. A. Latorre-Guzmán, C. I. Kado, A. C. Goheen, and T. A. Shalla. 1977. Reinvestigation of the role of a lactobacillus associated with leafhopper vectors of Pierce's disease of grapevines. Phytopathology $67: 298-301$.

21. Rogosa, M. 1974. Genus Lactobacillus Beijerinck, p. 576-593. In R. E. Buchanan and N. E. Gibbons (ed.) Bergey's manual of determinative bacteriology, 8th ed. The Williams and Wilkins Co., Baltimore.

22. Rogosa, M., and P. A. Hansen. 1971. Nomenclatural considerations of certain species of Lactobacillus Beijerincki. Int. J. Syst. Bacteriol. 21:177-186.

23. Rogosa, M., J. A. Mitchell, and R. F. Wiseman. 1951. A selective medium for the isolation and enumeration of oral and fecal lactobacilli. J. Bacteriol. 62:132-133.

24. Saito, H., and K.-I. Miura. 1963. Preparation of transforming deoxyribonucleic acid by phenol treatment. Biochim. Biophys. Acta 72:619-629.

25. Salton, M. R. J. 1964. The bacterial cell wall. Elsevier Publishing Co., Amsterdam.

26. Somogyi, M. 1930. A method for the preparation of blood filtrates for the determination of sugar. J. Biol. Chem. 86:655-663.

27. Spurr, A. R. 1969. A low-viscosity epoxy resin embedding medium for electron microscopy. J. Ultrastruct. Res. 26:31-43.

28. Whittenbury, R. 1966. A study of the genus Leuconostoc. Arch. Mikrobiol. 53:317-327. 